\title{
Sustainability values for business: A perspective of value alignment in a supplier-client relationship for case aqualogy
}

\author{
Carlos Humberto Hurtado Jaramillo ${ }^{1}$ (D), Nuria Arimany-Serrat ${ }^{1}$ (D), \\ Dulcinea Meijide Vidal ${ }^{2}$ (D), Xavier Ferràs-Hernandez ${ }^{1}$ (D) \\ ${ }^{1}$ Universitat de Vic (Spain) \\ ${ }^{2}$ Agbar, Aqualogy (Spain) \\ hurtadoja@gmail.com,nuria.arimany@uvic.cat,dulcinea.meijide@suez.com,xavier.ferras@uvic.cat
}

Received June, 2017

Accepted January, 2018

\begin{abstract}
Purpose: The study's goal is focused on determining a common set of sustainability-related issues and drivers relevant for business-makers, for being used as a framework to inter-organizational communications and thereby to reduce value perception dissonances on supplier-client business relationships.
\end{abstract}

Design/methodology: The study was methodologically based on a documentary review and different work sessions (interviews, workshop, and discussion) with a focus group composed of decision-makers in the water industry sector, of both the supplier and the client company.

Findings: The study makes as main contributions a differentiation within the scope of 'sustainability practices of global interest' and 'sustainability practices into business scope' from the business-makers' value perception, providing a set of sustainability value drivers, allowing reduction of value dissonances in business relationships, shedding light on solutions' value creation capacity and at the same time enhancing inter-organizational communications.

Research limitations/implications: The final set of sustainability-related issues (and drivers) presented aren't exhaustive and are delimited by the particular scenario generated around Aqualogy's business scope; therefore, it cannot be considered as a standard application mode.

Practical implications: This study sheds light on the importance of aligning business expectations around sustainability, and create a value framework that can be useful for fully embedding sustainability into the portfolio, business models, marketing strategies, technologies, and manufacturing processes. This framework can also be useful for analysing value dissonances on supplier-client relationships, identifying value gaps into business models.

Originality/value: The empirical study provides detailed insight into how the key decision-makers understand and perceive the sustainability value concept in the mainstream business. The alignment of their value perception shows to companies which sustainability values are expected in business, and how business strategy must use them as value creation drivers.

Keywords: Sustainability value, Value creation, Business value alignment 


\section{Introduction}

The first of January 2016 has been a landmark day in the global calendar as it witnessed the official implementation of the 'Agenda 2030 for Sustainable Development Goals' (SDG), which aims to establish within the next 15 years, a world which would be more responsible, balanced and equitable. The European Commission memo 'ECOM (2015) 497' had already been issued on October 14, 2015 in Brussels. A communiqué was drawn up urging member states to use trade and investment policy in a way that best contributes to meeting the SDG as penned down in the Agenda 2030, which at large would benefit businesses, consumers and workers in the long run. This new scenario would serve as a strong foothold for firms facing the challenge of incorporating sustainability values into their business models, marketing strategies, technologies and manufacturing processes among other aspects (Buxel, Esenduran \& Griffin, 2015; Nidumolu, Prahalad \& Rangaswami, 2009). However, although the sustainability concept has become a business vision, it is still unclear how it could be integrated into strategies that allow generating offers that meet the interests and concerns of customers (Biju, Shalij \& Prabhushankar, 2015; Chou, Chen \& Conley, 2015; Tukker, 2015; Dyllick \& Muff, 2016).

For working on the Agenda 2030 objectives, it is necessary to make strategic business-to-business (B2B) relationships and, to manage them directly and actively. Accordingly, the sustainable value creation from B2B relationships is a crucial source of competitive advantage for companies (Buxel et al., 2015; Vandaele \& Decouttere, 2013). LaPlaca (2013) Editor-in-chief of Industrial Marketing Management magazine, highlights how academic communities and experts in business-to-business (B2B) environments have increased their interest in this field; however, although the literature exposes a large number of issues to qualitatively or quantitatively assess how much sustainability is embedded in business (e.g. Global Reporting Initiative, Dow Jones Sustainability Index, etc.) these issues have inexorably been considered as main value criteria in business for both clients and suppliers, without considering their expectations or particular interest about sustainability-related issues (SRI) within business scope (Berns et al., 2009); consequently, the result offered by these instruments does not fully satisfy the needs or expectations that decision-makers demand to decision making (Biju et al., 2015).

While it is true that products and services by themselves provide some degree of inherent sustainability, it is also true that it is necessary to determine, clarify and highlight its business contribution for creating sustainability values (Nidumolu et al., 2009; Chou et al., 2015); however, in order to effectively identify and incorporate these values, firms must primarily understand how to address sustainability from the point of view of business relationships (Biju et al., 2015; Chou et al., 2015). A general view of this scenario was analysed in a survey performed by The Boston Consulting, where it was found that more than 70 percent of experts surveyed responded their company has not achieved a clear business case for sustainability, and more than a half have stated the need for a better framework for embedding sustainability in business (Berns et al., 2009). In B2B context specifically, it is important to draw up the differential factors relating to both value perception and value creation, because firms must face the challenge of identifying and aligning the values, avoiding value dissonances within the mainstream business (Pinnington, Meehan \& Scanlon, 2016). Literature review evidenced that decision-makers and managers overall lack a common framework of relevant sustainability value drivers (SVD) based on sustainability-related issues (SRI) in a specific sector in order to face the challenge of embedding them into the portfolio, business models, marketing strategies, technologies, and manufacturing processes.

Based on this backdrop, the study's goal focused on determining a set of expected SRI and SVD for a particular business sector, in order to use this as an understanding framework for inter-organizational communications and thereby reduce value perception dissonances on supplier-client business relationships. For achieving our study goal, it was proposed to focus on the business scope of a company in the water industry sector. The methodology followed was based on 4 steps: Issues collection, identifying SRI through a documentary research methodology (Mogalakwe, 2009). Issues selection, screening process by mean of brief interviews with a focus group composed of company's product managers and clients. Issues specification, aligning the sustainability value and business expectation with a workshop. Drivers' definition, fitting the range of value dissonances based 
on business expectations with a final discussion. As a result, from a total of 1734 sustainability issues identified, there were defined only 24 SRI with high relevance in the mainstream business, turning them into drivers for creating value in the water industry sector (SVD). The 24 SVD form the company's understanding framework for inter-organizational relationships as well as value criteria specifically for managers and decision-makers.

The proposed understanding framework can be used as a complement of The Cambridge Value Mapping Tool (CVMT) created under scope of "EU FP7 Sustain Value project"; 24 SVD could be used to highlight the potential of sustainable value creation within the bundle of the portfolio's solutions, to redesign the business models or for assessing a single business unit (products, services, product-services, processes, etc.). Likewise, it provides business-makers a clear way to understand the meaning of sustainability value and how those contribute to business and, at the same time with the commitments of Agenda 2030.For validating its usefulness, a case study was proposed in Aqualogy's business scope, seeking to identify how much sustainability is embedded within their business units; for this, there was analysed the product manager's perception (PM) regarding solutions' capacity (a set of products-services) to create the 24 sustainability values. Based on this first feedback, a company can redesign strategies and value proposals to fulfil value gaps in their business models.

This paper makes as main contribution a value differentiation in relation to 'sustainability values of global interest' and 'sustainability values of business interest', especially from the business-makers' value perception. This differentiation provides a key set of SVD, allowing to reduce value dissonances in business relationships, shedding light on solutions' value creation capacity, and at the same time, enhancing inter-organizational communications.

\section{State of the art}

The state of the art was developed considering questions that have arisen around the study. Therefore, questions like what is the meaning of sustainability values from a business perspective? Which is the business scope where sustainability values start to be created? How many tools are there for facilitating sustainable value creation? And finally, based on weaknesses and gaps in other studies emerged the last question, what has not been done?

\subsection{Meaning of sustainability values from a business perspective}

De Chernatory, Harris and Dall'Olmo Riley (2000), investigated the literature about "value" in order to find the meaning of "value added"; in the review, they found that value is largely discussed in relation to pricing, consumer behaviour and strategy. According to them, 'value' within the pricing literature is defined as the assessment of benefits received and sacrifices incurred (from the customers' perceptions). Also, the value is defined by the consumer behaviour literature in terms of what the customer needs and what the customer desires. Finally, strategy literature defines value as "what buyers are willing to pay." The meaning of 'value' and the 'value perceptions' have received significant attention in business literature in a wide-range of issues, but most number of researchers on business field, keep defining value primarily in monetary terms (Anderson, Narus, 1999; Wilson \& Jantria, 1994). Others researchers use a broader concept of "value" in business scope, such as competitive gains, competencies created, social relationships, knowledge acquired, managerial time, etc. (Wilson \& Jantria, 1994; Vandaele \& Decouttere, 2013; Biju et al., 2015). Besides that, value for customers could also be expressed as a more individual view of a particular interest, desire or need. Thus, perceived value is bound to vary between business sectors, between customers, and within the supplier-client relationship. In B2B scope, a supplier provides several kinds of value or facilitates its creation along business relationships in many ways.

On the other hand, sustainability is a complex and contested concept without any universal agreement on a particular definition (Haugh \& Talwar, 2010). Despite at global level, there is a high familiarity with the sustainability terminology, its concrete meaning remains low, either in ordinary life as in business. An evidence of this it was presented in a study made in 2014, here it is exposed that the average Germans' knowledge with the term sustainability is low. The study's results showed that only $39 \%$ of the surveyed had some concrete idea of its meaning and less than about 4\% associated it with future-aware behaviour (Roeder, Scheibleger \& Stark, 2015). Furthermore, although in the business environment the sustainability management is today a practice 
widespread among major companies around the world, their contribution over sustainability's issues and challenges are not reverted in the state of the planet, according to some studies. As a consequence, a "big disconnect" is presented between micro-level progress, and therefore a macro-level deterioration (Dyllick \& Muff, 2016). A general view of this panorama it was found some years ago in a survey developed by The Boston Consulting Group in which there was questioned 'Will sustainability change the competitive landscape and reshape the opportunities and threats that companies face? If so, how?' In that, more than 70 percent of the managers, high-ranking executives, and other experts surveyed responded that companies have not achieved a clear business case for sustainability yet, and more than a half have stated a need for a better framework for embedding sustainability in business. (Berns et al., 2009).

As with value concept in business, sustainability has many other definitions, then, how have these blurred concepts been integrated into business literature? Figge and Hahn (2004) were the first researchers to coin the concept of "Sustainable Value Add". They defined it as "the size of the contribution of a company to more sustainability measured in monetary terms' and thereby propose in their study, a monetary measure of corporate contributions. Later, Van Passel, Van Huylenbroeck, Lauwers and Mathijs (2009) and Kuosmanen and Kuosmanen (2009) introduced sustainable value-added calculus based on the theory of productive efficiency. Afterward, last authors argued with Figge and Hahn in relation to benchmark from which the value must be measured (interest, desire or need). In turn, Faulkner and Badurdeen (2014) pointed that in business the term implies the use of production systems that minimize negative environmental impacts, conserve energy, natural resources, consumers, and economically rational. In a nutshell, sustainability value is defined as enhancing the firm's competitive advantage and simultaneously the counterparts' benefits in the business interaction (monetary and non-monetary).

Despite experts acknowledge that value meaning and value perceptions are based on an individual appreciation, inter-organizational communications remain being considered at the organizational level rather than social entities (Gligor \& Autry, 2012; Chou et al., 2015). Cause this, there are gaps regarding the role of managers' decisions, actions and perceptions around sustainability values and its influence on collaborative relationships within the business.

\subsection{Business scope for sustainable value creation}

It is important to acknowledge which are the key stakeholders responsible for value creation and business performance; thus, it would be recommendable to create participative strategies oriented toward these specific groups that require more attention to help them in the process of decision making. For many researchers, this is one of the most important aspects for building business relationships around sustainability (Dyllick \& Muff, 2016; Berns et al., 2009; Pinnington et al., 2016; Biju et al., 2015), as well as answering the question, what aspects do they value in economic, social and environmental business issues? (Hoekstra, 2015; Hohenschwert \& Geiger, 2015; Slabbert \& Barker, 2014; Vandaele \& Decouttere, 2013). Even today, many companies do not understand the role decision-makers play in the overall value creation processes, even though it is possible to find literature about that and specific methodologies that guide them (Graham \& Bertels, 2006; Hoekstra, 2015; Hohenschwert \& Geiger, 2015). Although for a company, there are wide range of stakeholders, decision-makers often are identified as being the driving agent of business, and therefore, key players in achieving goals as well as performance (Wilson \& Jantria, 1994; O'Cass \& Ngo, 2012; Schaltegger, Lüdeke-Freund \& Hansen, 2011). Despite this, little is known about the precise impact that decision-makers have on sustainable value creation, it is understood that it is essential to focus on the most important stakeholders as because companies have limited resources, and it is difficult to completely satisfy everyone. Given the central role of decision-makers, it is necessary to pay particular attention to the expectation and interest they have on sustainability.

Some researchers suggest segmenting the relationships, facilitating effective identification of specific sustainability interests, which in turn allows a strategic objective alignment for jointly creating business values (Juwana, Perera \& Muttil, 2010; Marchi, 2013; Prior, 2012; Chou et al., 2015). When in a business relationship, it is seeking higher value levels, the creation process requires continued joint efforts on sustainability context, the focus of this analysis, and it is dependent on the value alignment expectative in the supplier-client relationship. 
Therefore, a recent topic in business relationship literature (supplier-client) is the need to align and manage interorganizational interactions and interchanges to achieve value creation and generates competitive outcomes (Ambrose, Marshall \& Lynch, 2010; Schaltegger et al., 2011; Prior, 2012).

Peat (2003) was one of the first researchers to introduce the process of aligning business practices with valuebased pillars (economic, social and environmental). He emphasized that the main issue to make it work is that it must be both defined and understood clearly as well as properly communicated to employees, customers, investors and partners. Particularly, the value must be aligned between the business actors and their business expectations. By extension, the alignment facilitates the competencies and responsibilities identification. This way is to define how through the service interaction is possible to create or facilitate the sustainable value creation. Value alignment within business actors ensures that the suppliers facilitate exactly what counterparts expect to perceive.

The value creation importance is heightened in strategic B2B relationships which are not only episodic business exchanges, by the contrast, they are continuous and long-term interactions (de Chernatory et al., 2000; Lusch, Vargo \& Tanniru, 2009; Vandaele \& Decouttere, 2013). Indeed, themselves become valuable for the enhancement of organizational capabilities, inter-organizational learning, business stability and sustainability performance among others. Some papers highlight the interaction and dialogue processes between supplier and client as a common space for agreement in order to create sustainability values, which are more in harmony with their expectations (Lusch et al., 2009; Ballantyne, Frow, Varey \& Payne, 2011); other papers have also highlighted the supplier relational capacity to change, transform and improve the resources and activities of companies involved (O'Cass \& Ngo, 2012; Hohenthal, Johanson \& Johanson, 2014; Buxel et al. 2015).

Throughout the literature is stated that collaborative strategic relationships remain poorly studied and understood (Wilson \& Jantria, 1994; Prior, 2012). Indeed, in business practice are difficult to manage (Pinnington et al., 2016). As a result, the potential of collaborative strategic relationships for business is not being fully developed (Meehan \& Wright, 2013), and hence it is observed a high failure rate (Schaltegger et al., 2011). In this sense, researchers recognise the need to consider a greater and dynamic interaction into the business ecosystem (Lacoste and Johnsen, 2015). In fact, the collaborative strategic relationships for service contracts are acknowledged to be rarely performed by a single actor at a single point-in-time (Chandler \& Lusch, 2015; Pinnington et al., 2016). A B2B service wide-view moves the value scope from what a supplier is capable to provide to a customer, up to what all counterparts receive and perceive from the beginning of the service interaction, through to the end (Ford \& Mouzas, 2013; O'Cass \& Ngo, 2012).

\subsection{Extant tools around sustainability values}

Some researchers have developed an extant literature review to offer a complete analysis of frameworks, norms, qualifications and indices available to produce sustainability reports and assess corporate sustainability contributions; they conclude that due to the high variety and little standardization in focus, criteria, benchmarks and methodologies, it makes comparison difficult, therefore, they provide diverse explanation from different views about value and effects of sustainability on business (Lozano, 2012; Renard, 2015). Some other researchers state that in business relationships, specific criteria or value attributes are not usually determined; therefore, they pointed out that the lack of full acceptance is caused by the fact that the approach given to these tools does not completely satisfy either the company or the client (Berns et al., 2009; Biju et al., 2015; Dyllick \& Muff, 2016). It is proposed that further studies improve the ability to identify sustainability contributions, explore the interlinkages between them and consider the variability from the perception of the individuals involved.

Hart \& Milstein (2003)are the first business experts to build a framework based in the sustainability value concept for business. They tackled the question on how companies embed sustainability into their business strategy. They suggest its use by managers to determine business activity in each of the four quadrants described in their model in order to identify imbalance in its portfolio of activities. The framework was built taking as base global drivers and challenges of sustainability to identify strategies and practices that contribute to achieve simultaneously both SDG and shareholder value. For using this tool, the manager's first step toward the creation 
of sustainable value within the business is thinking through a wide and full range of challenges and opportunities. To sum, model is based on the activities organization across discrete projects and business experiments.

Juwana et al. (2010) developed a conceptual framework of water sustainability index for West Java(WJWSI). The method is composed by three main parts: components, indicators/sub-indicators and threshold values. For built framework there were invited lecturers, government officials, consultants and community representatives in their role of water-related stakeholders. As result, the water sustainability index provides information on the current conditions of water resources, as well as the priority of water issues. Although WJWSI is a powerful tool for water utilities, its limitations to highlight value creation process in business is evident.

Similarly, Yang, Vladimirova, Rana and Evans (2014) purposed in their study a sustainable value analysis tool (SVAT) in order to help manufacturers identify opportunities to create sustainable value by means to analyse 4 specific aspects: product life cycle, value proposition, uncaptured value and value opportunity. SVAT combines the life cycle thinking and the analysis of different value forms. Sometime later, the same authors accompanied by Dr. Samuel Short, Dr. Nancy Bocken, Dr. Dai Morgan, Dr. Lloyd Fernando, Dr. Curie Park, Dr. Fenna Blomsma and Dr. Maria Holgado in the scope of "EU FP7 Sustain Value project" create The Cambridge Value Mapping Tool (CVMT). This last tool was built recently, and it has been developed to identify failed value exchanges among multi-stakeholders in the firm network uncovering new value opportunities. Like SVAT, CVMT having accounted for the analysis of different value forms. Further, Evans, Fernando and Yang (2017) describe and analyse in their study the strengths and weakness of the CVMT, and the SVAT.

Above studies suggest that companies must consider the value creation from multi-stakeholders view (i.e. customers, suppliers, employees or even society), but in fact, from the Corporate Social Responsibility they are already considered in order to identify how they perceive the global company' practices in regard to SDGs (i.e. corporate materiality report) and so, to build a new corporate strategy. Therefore, suppliers must consider a value alignment taking account client perspective in order to making decisions within the mainstream business (for embedding sustainability into the mainstream business).

The studies show how authors developed their works by linking business activities with sustainability issues, some considered multi-stakeholders with specific sustainability issues and some linked customer requirements with life cycle thinking to identify multi-dimensional forms of value. As it already relates in the previous literal, identifying together business and sustainability challenges will drive business makers to the reduction of failures in embedding sustainability in the mainstream business as well as reduction of risk because value dissonances among them. Therefore, the previous tools lack in a common base for decision-makers about a set of sustainability-related issues (SRI) that can be used as relevant value-drivers (SVD) for the business development process. Therefore, it is a goal of this study to propose a link between supplier-client interests with specific sustainability issues in water industry sector in order to identify value perception differences in business relationships.

\subsection{Weaknesses and gaps}

Most companies still maintain a business value approach focused on equipment functionalities, productivity performance, market evolution and financial performance, while ignoring other value generating factors, which in fact also affect a business' overall balance (Bocken, Short, Rana \& Evans, 2013; Vandaele \& Decouttere, 2013). Over time, sustainability value has gone on to become part and parcel of literature, especially when it comes to rethinking the strategy of embedding sustainability in business, or any contexts driven by the desire to combine new value propositions aimed at achieving greater customer satisfaction through them (Peat, 2003; Tukker, 2015). However, although extant literature explores sustainability contributions in business performance, it is also true that there are gaps in how to align supplier-client requirements on sustainability business interests, and how this void tends to have an impact on the value creation process and its assessment (Van Passel et al., 2009; Doualle et al., 2015; Zijp et al., 2015). This failure in value alignment is often due to the limited understanding and identification of the appreciative value criteria in a supplier-client relationship or collaborative relationships. 
Despite there is a wide range of supporting tools and guidelines in the study scope, it is still a lack of clarity in explaining how those address the value perception of the key actors in business relationships as well as the different SRI they consider relevant for making decisions around value creation process.

Some steps in CVMT start asking the possible analyst: "Who are the stakebolders for the unit of analysis" and "What is the purpose of the unit of analysis" According to the first question, the present study considers as main stakeholders in business relationships are those stakeholders that have a high relevance at the moment to take commitments and mainly decision making. Therefore, managers have a big responsibility about accountability for either business performance or value creation on sustainability. Key stakeholders in a business relationship (e.g. managers, executives or decision-makers) have to consider a specific understanding framework in which their business relationship is based. The proposed goal in this study seeks to align sustainability interest from both clients and supplier, in terms of company building and understanding framework, so that a decision maker can best position the sustainable value creation process along with the business relationship.

From the literature review, it is suggested that by finding out what SRI and business practices are in dissonance on the supplier-client relationship, then figure out what to do with these value gaps or misunderstandings along business relationships is the best way to come up with an inclusive proposal (SVD) for creating sustainability values. But for this, it is necessary to know and have control over the set of defined value criterion within a business relationship. On the second question, this study looks to determine the gaps on value perception which are present in a business unit of analysis (portfolio' practices or solution practices). In other words, for creating sustainable values and, in turn business opportunities, it is necessary to identify the sustainability value missed or mark the value absence within a business unit of analysis.

Likewise, there is limited emphasis on applying sustainability value analysis in service sectors to support decision makers at a business level. Thus, the combination of product-service attributes and SVD like an integral solution package requires a dyadic communication as base of product-service design. This way, within the business scope, one can properly evaluate and address commonalities and differences (even conflicts), between client and supplier in relation to measurement of sustainability contributions. Therefore, in order to really embed sustainability in the mainstream business is essential to align sustainability interest both clients and supplier determining business dissonances on sustainability values in the business practices. The outcome of the process is a business value framework, so that decision-makers can best positioned sustainable value creation strategies along business relationship.

\section{Methodology}

The study had a goal to determine a set of common set of sustainability-related issues (SRI) and drivers (SVD) relevant for a company in the water industry business, in order to be used as an understanding framework for inter-organizational communications. For this, it was necessary to follow 4 steps which are illustrated below:

- $1^{\circ}$. Issues collection, it is a documentary research methodology that implies a phenomenon study and analysis from different documents which provide key information (Mogalakwe, 2009). The process aimed to establish a broader number of SRI outside company sources to avoid internal influences and update extant information.

- $2^{\circ}$. Issues selection, it is a screening process based on interviewing a focus group or panel experts, and through them, a greater understanding or judgment on a specific topic is achieved (Juwana et al., 2010). The process aimed to align particular interests on the sustainability (both the client and the supplier) within the mainstream business. It was developed by means of brief interviews with a target group composed of the main actors into Aqualogy's business scope (product managers and internal clients).

- $\quad 3^{\circ}$. Issues specification, it is a screening process based on a workshop with the focus group; it was developed by means of cross-reference information from eight archetypes of business sustainability. This process aimed to select issues with a high relation degree within the business. 
- $4^{\circ}$. Driver determination, it is a process to establish a final set of drivers through a discussion with the focus group. It is seeking to capture common criteria of SRI and their expectations. The process aimed the analysis of value perception, constraints and opportunities in the current time. This way, it was possible to reduce the value dissonances about sustainability meaning within the mainstream business. At the end, the final set of value elements was considered as the understanding framework to Aqualogy's business scope.

\begin{tabular}{|c|c|c|c|}
\hline Steps & & Process & Technique \\
\hline $\mathbf{1}$ & Issues collection & Identify broader range of SRI & Documentary Review \\
\hline $\mathbf{2}$ & Issues selection & Specific issues or topics in business scope & Focus group Interview \\
\hline $\mathbf{3}$ & Issues specification & Business expectation alignment & Focus group Workshop \\
\hline $\mathbf{4}$ & Driver determination & Reduce range of value dissonances & Focus groupDiscussion \\
\hline
\end{tabular}

Table 1. The followed steps to develop the study

\section{Sustainability value framework}

The present study concentrates on Aqualogy, a service company in the water industry sector, and especially in its business scope (product managers and internal clients). Below it has detailed the steps were taken to determine the set of SRI in its business relationship.

\subsection{Documentary research}

Documentary research was mainly based in: a study developed by Global Reporting Initiative (GRI, 2013). Materiality Reports from five companies in the water industry sector (Suez Spain, Veolia, Acciona, and FCC). A literature review based on B2B sustainability interests. Because of the huge amount of SRI collected (1734 approx.) it was decided to classify and cluster them in order to reduce their specificity level. Conceptual and contextual importance and their relations have been recognized and exploited in many research studies where its usefulness focused on text processing tasks, information retrieval, semantic analysis, selection, classification, and clustering (Huang, Milne, Frank \& Witten, 2012). Hence, SRI was classified into core topics according to each context, similarity or conceptual overlap, reducing their figure until a total amount of 478. Afterwards, they were hierarchically classified under three dimensions (economic, social and environmental) (Table 2).

\begin{tabular}{|c|c|c|c|c|c|}
\hline & & Economic & Social & Environmental & Others \\
\hline 1 & Documentary research & & & & \\
\hline 1.1 & GRI, 2013 & 208 & 725 & 612 & 67 \\
\hline 1.2 & Materiality Reports & & & & \\
\hline 1.2.1 & FCC & 1 & 9 & 6 & \\
\hline 1.2.2 & Veolia & 6 & 5 & 8 & \\
\hline 1.2 .3 & Acciona & 5 & 9 & 4 & \\
\hline 1.2.4 & Suez Spain & 9 & 15 & 6 & \\
\hline \multirow[t]{3}{*}{1.3} & Literature Review & 15 & 14 & 10 & 0 \\
\hline & Total & 244 & 777 & 646 & 67 \\
\hline & Clustering by context & 69 & 221 & 188 & \\
\hline \multirow[t]{2}{*}{2} & Focus group - Interview & & & & \\
\hline & Laddering questions & 22 & 65 & 37 & 0 \\
\hline \multirow[t]{2}{*}{3} & Focus group - Workshop & & & & \\
\hline & Questionnaire & 12 & 33 & 16 & 0 \\
\hline \multirow[t]{2}{*}{4} & Focus group - Discussion & & & & \\
\hline & Final set & 8 & 8 & 8 & 0 \\
\hline
\end{tabular}

Table 2. Steps for identifying SRI and SVD in water sector 


\subsubsection{Global reporting initiative}

In July 2012, the GRI initiated a research project to map the issues considered relevant by different business groups; the resultant of this project turned out to be a publication in May 2013 titled "Sustainability-related issues for the sectors: what do stakeholders want to know?" (GRI, 2013). A total of 194 organizations related to different interest groups participated; as a result, a total of 2812 topics and sub-topics were generated, of which a total of 1612 were related to 52 business groups that participated in the project. The lists provide a glimpse of the current sustainability problems considered relevant to the sectoral groups surveyed and from the different stakeholder's point-view. The information is presented in 128 tables, in which the 52 sectors are distributed. Each table presents five aspects: the sustainability dimension, the proposed theme (criterion), a simplification of the theme (sub-criterion), its constituency (competence) and finally the references. Likewise, each sector was split further into 4 specific dimensions (economic, environmental, social and others). Each sub-dimension had a list of subjects and sub-themes that correspond to a constituency; the topics and sub-topics included are supported by documental references validating them.

\subsubsection{Materiality reports}

Organizations are challenged to report publicly relevant topics that may reasonably be considered important for reflecting their economic, environmental and social impacts, or those that influence the decisions of stakeholders. Accordingly, materiality is the threshold at which aspects become sufficiently important that they should be reported. To develop the report, companies raised the following questions: 'What does it really matter on sustainability?' 'Who the stakeholders are?' 'How are sustainability issues being managed?'

Usually, companies carried out a review and identification of issues in relation to the associated GRI-G4 indicators, the relevance of the issues identified are assessed taking into account external sources of information, based on the opinion of interested prescribers, such as international organizations, sectoral institutions, press and media, industry associations and international standards. Subsequently, the relevance of material matters is assessed according to the peers analysed. From the last process, emerges the corporate materiality report which is disclosed to community every expired year.

The review of the materiality reports disclosed by the four companies in the water sector highlighted a total of 83SRI, considered the most important or relevant for the year 2014. (30 from Suez-Spain, 19 from Veolia, 18 from Acciona, and 16from FCC).

\subsubsection{Literature review}

To ensure validity of the review, a specific literature was compiled in the period from 2005 to 2015. For this, a search of articles was made from the combination of keywords in the databases of Scopus, Science Direct and Isi Web Knowledge (sustainable value, customer value, value added, sustainable value added, and sustainable product-service). This search was directed to articles with high competence in the subject and was considered in the first level journals within the specified discipline of study. In order to structure the search and orient it to the main objective of the study, 4 questions were asked: 'What aspects of sustainability bring benefits to the business interests of the client?' "Which of these are key to achieving better business performance?' 'Can the recognition of sustainable value improve the client-company relationship?' 'How does this value influence supplier-client commitments?"

A classification scheme was used as a basis for organizing the responses, which in turn served to guide research towards the selection of key issues. Subsequently, the articles were split based on three conditions: the first was the field of study- selected articles associated with sustainability taking into account the vision of customers, managers, experts. The second was the main topic of study, so it had to address or resolve some of the questions raised. The third was the approach given by the author wherein articles were selected based on the orientation to the perception of customer value, customer-company and supplier-client relations. Then, based on the information collected from 54 articles, a list was drawn up containing 39 aspects, which according to the authors have some interest for both clients and firms. 


\subsection{Focus group - Interview}

Considering value perception of every part of business relationship regarding SRI represents a big step forward for integrating sustainability in business. This allows companies to align common issues for co-creating value through product-services offered. Therefore, focus group interviews was the technique selected for aligning SRI around mainstream business.

Interviews were based on a sequence of semi-structured question related to focus group interest in sustainability. Laddering questions were formulated from a general context to a singular one: The first, there was an open question about the personal perception of SRI from companies. Which sustainability aspects do you perceive from companies? The second, there was a question about what are the SRI that can generate benefits, especially for business. What kind of SRI can benefit global business overall? The third question was over the expected benefits in the sector. What kind of SRI can contribute the water industry sector? The fourth question was about the particular SRI that they perceive from the products-services. "What value has that sustainability you perceive within the mainstream business?

The answers given facilitated to exclude those SRI that were discarded by the interviewee because of their low perception level of importance, or because there were simply not mentioned. The new screening process led to a total of 124 issues (Table 2).

\subsection{Focus group - Workshop}

The workshops were conducted to better understand how focus group perceives sustainable issues selected, in order to centre their business expectation and at the same time continue with the alignment of core SRI. Initially, the workshop was oriented to understand the eight archetypes proposed by Bocken, Short, Rana and Evans (2014) that seeks to explain business model innovations for sustainability and provide a starting point to assist the process for embedding sustainability in business models (See Appendix A).

Afterwards, focus groups were asked to complete a short questionnaire with 142 SRI hierarchically classified under economic, social and environmental dimensions. The questionnaire included structured closed questions, with a dichotomous answer (e.g. Considers that "the sustainability issue" respond to one or more than one of the eight archetypes? yes or no). The respondents were asked one of the three dimensions at a time, answering each one of the issues presented. Questionnaires were answered in a sequential order to ensure unnecessary bias was not introduced among them. Finally, a new screening was made taking into account two considerations: there were chosen those SRI which have been answered positively by most of the respondents. Second, there were chosen those SRI that could be measured and those that must be measured. The new screening process leaded until a total of 61 issues (Table 2).

\subsection{Focus group - Discussion}

For the last step, the focus group was guided by a moderator who introduced the study developed by Dyllick and Muff (2016) and which is related to the business sustainability typology they created to distinguish when a business is really sustainable. The 61 issues hierarchically classified under three dimensions were put to discussion, considering the six questions proposed by Dyllick and Muff in their study. Five of the six questions were reformulated for the group to focus on how SRI can affect the mainstream business and vice-versa (See Appendix B).

Moderator presented the set of 61 discussion topics and, helps the group to participate in a lively and natural discussion amongst themselves. Also, it was considered that the last screening process showed a difference in the number of components as well as its level of specificity; therefore, it was necessary to reconcile and balance the issues contained in each dimension. Focus group identified a set of 24 SRI that helps to reduce value dissonances, determining an understanding framework for business relationships in the water industry sector. Table 3 contains the common SRI (and sustainable values drivers) that reflect the economic, social and environmental expectations of the sector in which they operate. 
The set of SRI because of their high relevance to focus groups, representing a value framework to assist supplier companies in dyadic communications for embedding sustainability in mainstream business by means of an understanding framework which clarifies its contribution not only to business scope, also to global scope. Those issues support Aqualogy for analysing its product-service system as well as its improvement process of sustainable value creation (i.e. through co-creation, co-development and co-innovation). The set of SRI can be seen as a value criteria framework for performing business units' value analysis (i.e. each one of solutions within the portfolio offering).

The set presented in Table 3 is delimited by the particular scenario generated around Aqualogy's business scope; therefore, it cannot be considered as a standard application model, nor is it a definitive list, since the interests of both clients and the firm will evolve over the time.

\begin{tabular}{|c|c|c|c|}
\hline & & & \\
\hline & & Business Expectation & Sustainability Value Drivers \\
\hline \multirow{8}{*}{ Economic } & 1 & $\begin{array}{l}\text { Ensuring competence and effectiveness organizational } \\
\text { through practices and strategies }\end{array}$ & $\begin{array}{l}\text { Proficiency and effectiveness } \\
\text { improvement }\end{array}$ \\
\hline & 2 & $\begin{array}{l}\text { Managing expenses and cost regarding operations and } \\
\text { consumptions }\end{array}$ & Expenses and cost management \\
\hline & 3 & $\begin{array}{l}\text { Optimizing production performance by means of } \\
\text { products-services }\end{array}$ & Production performance \\
\hline & 4 & Incremental economic performance & Economic performance \\
\hline & 5 & Managing innovation, creativity and technological insights & $\begin{array}{l}\text { Incremental innovation and technology } \\
\text { insights. }\end{array}$ \\
\hline & 6 & $\begin{array}{l}\text { Managing adaptability and flexibility to create, design or } \\
\text { restructuring products-services and activities }\end{array}$ & $\begin{array}{l}\text { Managing creation and adaptability } \\
\text { capabilities }\end{array}$ \\
\hline & 7 & Managing knowledge development & Incremental knowledge management \\
\hline & 8 & Resource efficiency management & Incremental resource efficiency \\
\hline \multirow{8}{*}{ Social } & 1 & $\begin{array}{l}\text { Ensuring employees health and safety through working or } \\
\text { labour conditions }\end{array}$ & $\begin{array}{l}\text { Making a health and un-risk labour } \\
\text { scope }\end{array}$ \\
\hline & 2 & High quality and safety of products-services & Incremental quality and safety \\
\hline & 3 & $\begin{array}{l}\text { Ensuring organizational integrity, ethics and accountability } \\
\text { through business practices, rule employed and strategies }\end{array}$ & $\begin{array}{l}\text { Ensuring compliance with transparent } \\
\text { behaviour }\end{array}$ \\
\hline & 4 & $\begin{array}{l}\text { Interaction, engagement and relationships management } \\
\text { with stakeholders }\end{array}$ & $\begin{array}{l}\text { Making long-term and strategic } \\
\text { connections }\end{array}$ \\
\hline & 5 & $\begin{array}{l}\text { Information, data and content availability in marketing, } \\
\text { social media and communications regarding products- } \\
\text { services }\end{array}$ & $\begin{array}{l}\text { Information, data and communications } \\
\text { availability }\end{array}$ \\
\hline & 6 & $\begin{array}{l}\text { Managing proficiencies, talent and capabilities on } \\
\text { employees }\end{array}$ & $\begin{array}{l}\text { Proficiencies, talent and capabilities } \\
\text { generation }\end{array}$ \\
\hline & 7 & Incremental employment' quality and talent retention & Incremental employment' quality \\
\hline & 8 & Water availability and management for the beneficiaries & Expanding network service \\
\hline \multirow{8}{*}{ Environmental } & 1 & $\begin{array}{l}\text { Treatments/management on emissions and wastes with } \\
\text { contaminant/hazard charge }\end{array}$ & $\begin{array}{l}\text { Ensuring compliance with } \\
\text { commitments }\end{array}$ \\
\hline & 2 & $\begin{array}{l}\text { Management of generation, collection, selection and } \\
\text { disposal of wastes }\end{array}$ & Managing and recovering wastes \\
\hline & 3 & Treatment and management of water and wastewater & Managing and treatment wastewater \\
\hline & 4 & $\begin{array}{l}\text { Managing consumptions, loss or underutilization of } \\
\text { resources }\end{array}$ & $\begin{array}{l}\text { Consumption, loss and underutilization } \\
\text { resources. }\end{array}$ \\
\hline & 5 & Managing raw materials source-based & Raw materials source dependency \\
\hline & 6 & $\begin{array}{l}\text { Reuse, recycle or any treatment which turn products on } \\
\text { useful again, any circular economy practice }\end{array}$ & Incremental circular economy \\
\hline & 7 & Managing and protecting ecosystem & Ecosystems protection \\
\hline & 8 & Energy efficiency generated by products-services & Incremental energy management \\
\hline
\end{tabular}

Table 3.Sustainability-related issues for Aqualogy business relationship 


\subsection{Sustainability value forms in business}

The set of common sustainability values can be considered as a complement to 'The Cambridge Value Mapping Tool and 'The Sustainable Value Analysis Tool mentioned above. Therefore, having in count that some initial steps suggested by the tools are implicit from the beginning in the present study, and once it has been defined that units of analysis are either portfolio's activity or a single business unit of analysis (solutions, product or services). Thus, decision-makers can use the tools in order to answer the question about sustainability value forms associated with the business (value captured, missed, destroyed, surplus, absence and opportunities).

\section{Case study: Aqualogy Solutions}

Aqualogy Solutions is a service company which offers a bundle of solutions in the water industry sector; this company is part of Agbar group's holding, which is steeped in over 145 years of history and comprising of more than 128 companies that operate in the service sector of the integral water cycle, serving more than 26 million inhabitants. Currently, most companies in the water industry sector have a certain grade of servitization, for this, offering diverse solutions related to water, energy, and materials. Servitization is a trend in which organizations create and deliver multiple value-forms through the capabilities of a set of product-service (solutions) (Xing, Wang \& Qian, 2013; Bocken et al., 2014). Therefore, sustainable value creation by servitization is directly related to enhancing the solutions' capabilities to serve not only customer demands but also supplier competence (Bocken et al., 2013). In practice, when executive decisions are consistent and aligned with business interest and expectations, that is, when there is an "interest alignment" between supplier and client goals, it can empower the enhancement of servitization capabilities and in turn to create competitive advantage.

Therefore, a case study was proposed seeking to identify how many of SVD are embedded in the Aqualogy's portfolio; for this, it was proposed to use the framework to know the product managers' value perception (PM) in regards to solutions' capacity (set of products-services) to create sustainability value. The case study looks for highlight the importance of value framework in the business developing, and so to address the challenge of embedding them in business relationships. Based on this feedback, the company can re-design strategies and value proposals to fulfil value gaps in their business models.

The case study was developed in 3 steps. The first step, started with a selection of a small sample of solutions from the portfolio, taking into consideration sales volume, market time, innovation-content, and differentiation (some solutions selected are exclusive to Aqualogy). In this step, a sample of eleven solutions was determined (PS), representing approximately $12 \%$ of the total offering to the portfolio. The second step, it was built an "attribute-value" relational matrix as an analytical tool to estimate the potential of value creation. For this, it was made a cross-relation between solution's attributes and the sustainable value drivers (PS attributes vs SVD). For the third step, there were contacted the respective PM in order to invite them to participate. They were asked to complete the matrix taking into account the potential of solution's attributes for creating related values in the existent business relationships. Accordingly, every PM evaluated the solutions using a scale ranging from 0 "capability not perceived" up to 3 "capability extremely perceived", making the value perception congruent with the proposed understanding framework. As result, a total of 11 PSs were evaluated individually and the scores are represented by small different colours shapes/marks. So, the number of shapes/marks in the figures reflects the potential capability of every solution for creating sustainability values. The results only show the personal perception of the product managers. Finally, the results are presented, initially from a global view and later in an individualized way by every sustainability dimension.

Figure 1 facilitates the comparison of the solutions (PS) in relation to their potential capability for creating value in every one of the three sustainability dimensions. This Figure 1 shows eleven comparative curves, where their potential capability is measured in percentage. Every solution is represented by a specific curve and colour. 


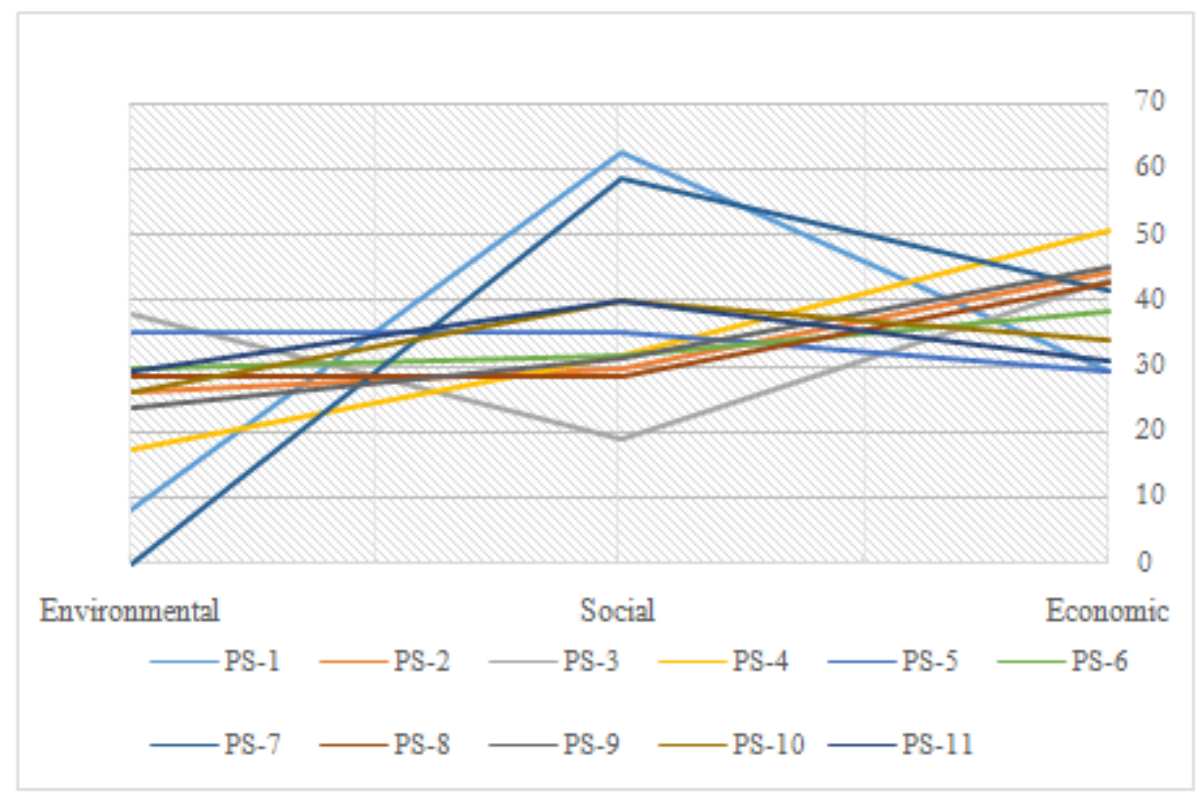

Figure 1. Solutions' capabilities in the three sustainability dimensions

The curves present a distribution that mainly shows the perception differences between product managers about solutions' capability to create economic, social or environmental values. At first glance, it is observed that approximately $72 \%$ of PSs have scores that range from $30 \%$ up to $40 \%$ of "potential capability" for the three categories; but unusually, $36 \%$ of PSs in the environmental dimension oscillates in a medium-to-low score from 30 to $0 \%$.

These particular results have their roots in a narrow or fair conception of 'value proposition' rather than in fully offering that inherently have the PSs, but this will be analysed later. As for the social dimension, it is possible to appreciate a greater tendency towards "potential capabilities" favourable perception. Here, the scores ranging from the highest $(64 \%)$, which clearly agree with the orientation outlined in the materiality report and the company strength, to the lowest (20\%), only represented by the PS-3.

From a global view, the "potential capabilities" perception of the economic dimension presents scores with an average range, varying between 30 and 50\%. In this aspect, the PSs sample reflects a well-balanced creation potential that has its roots in current value propositions where there is put a special emphasis on the monitoring of economic dimension.

Figure 1 offers a picture of the hypothetical "potential capabilities" of the studied sample, always based on the product manager's perception and their influence on the value proposals. Then, this methodology helps managers to analyse and deep the why of the low and high perception levels relative to sustainable value creation. In this way, it is possible to determine new actionable strategies to strengthen business strategies around business models. A very singular aspect of the results was the low score in the environmental dimension given by some PMs, even though Aqualogy focus its efforts in this area. According to some of them, environmental values are already inherent in the PSs and therefore are implicit in the business itself. Results show, at least in this analysis, that the main aspect to be remedied is to adjust at the company internal level, the value perception of the SVD. For this, it is necessary to use tools which help to discriminate the "potential capabilities" of the solutions as sustainable value creators. Applying this methodology at the corporate internal and external level can help managers to highlight those capabilities with high potential for value creation and re-evaluate those with low potential in order to promote actions tending to re-design the product-service set. As annotation, the understanding framework is subject to reconcile and balance the SVD that can be measured and those that must be measured. Therefore, adjusting of the PSs value proposal necessarily requires being accompanied by the respective performance indicators in order to validate the value creation. 
Afterwards, the results are presented in an individualized way for every sustainability dimension, summarizing them in 3 figures (economic, social and environmental). In each figure, the horizontal axis represents the sample of PSs (from 1 to 11), and the vertical axis represents the "potential capabilities" level perceived by PMs. Likewise, every SVD is represented by small colour marks. This means that to a greater and higher number of value marks, the greater will be the value potential perceived by PMs.

\subsection{Value drivers: Social dimension}

In figure 2 at first glance, it is observed that even though the PS- 6 presents a more value drivers diversity than the PS-1, the PS-1 has the higher potential capability among the few value drivers perceived. This means that in a business model is not only sufficient to offer a wide value diversity because could happen that the key value of differentiation can be being diluted. Likewise, those PSs with very little value drivers perceived (PS-1, PS-3) and high potential-capabilities evidence a biased or narrowed social value proposition in their business model. In business is essential to emphasize the value drivers with greater strength within the proposal, including those that will be directly or indirectly linked to the service, making more attractive the value proposition. (e.g. PS-7, PS-9, PS-10 and PS-11).

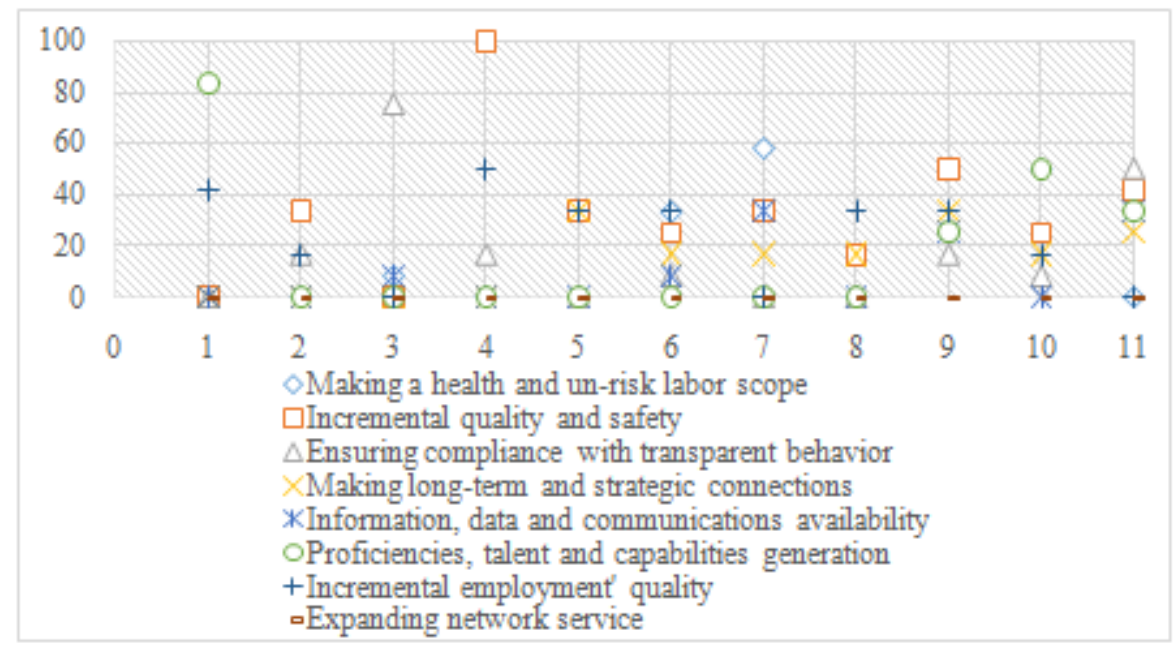

Figure 2. Capability to create social values

In the social dimension, the PSs- $(2,4,5,6,7,9,10$, and 11) have proposals aimed to improve the conditions of quality and safety. At a comparative level, these value-drivers stand out among other value drivers, showing potential-capabilities that range between 20 and 55\% (only PS-4 is upper). For their part, the PSs- $(1,4,5,6,8$, and 9) are aimed to improve the incremental employment' quality with scores between 20 and 55\%. Also, the creation of proficiencies and talent to clients and employees is related to PSs- (1, 9, 10, and 11), their score oscillates from 20 up to $84 \%$. Meanwhile, with a few value drivers perceived and very low levels of potential capability were found PSs- $(2,3,5$, and 8$)$.

\subsection{Value drivers: Economic dimension}

In the economic dimension, PMs expressed that for every business unit there is a value proposition in which is considered the inherent 'sustainability performance' improvement by reducing operating costs and an efficient management of resources (current business strategy). According to them, the value proposal must be conformed to client expectations and demands in regard to the potential economic impacts. However, this thought was not reflected in the outcomes. 


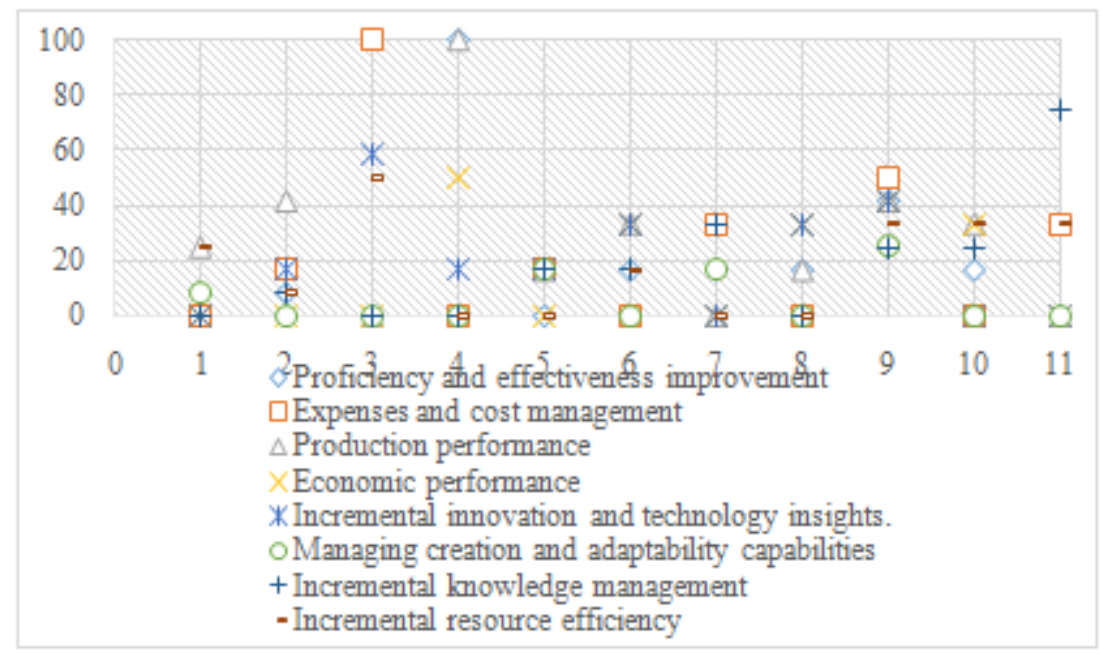

Figure 3. Capability to create economic values

In Figure 3, the PSs- (3, 7, 9, and 11) focus their proposals on optimizing expenses and costs management, showing potential-capabilities that range between 35 and 55\% (only PS-3 its upper). Also, the PSs- (1, 2, 4, 6, 9, and 10) are oriented to enhance the production performance, and their scores oscillate from 20 to $42 \%$ (only PS4 its upper). Meanwhile, the PSs- (1, 3, 9, 10, and 11) aimed to pursue incremental resource management (scores from 28 to 55\%). At a comparative level, the PSs- (9, 10, and 11) share their approach in the production scope (cost and resource management to increase performance).For their part, the value driver which is addressed to incremental innovation and technology is found in the PSs- (3, 6, 8, and 9) with scores between 28 and 58\%. Regarding value driver aimed at incremental knowledge management is related to PSs- (7, 9, 10, and 11). Interestingly, PS-11 presents a high potential capability focused on driving the knowledge management as well as the PS-9 and PS-3. These PMs recognize that knowledge and technology have a greater impact on business, mainly because these value-drivers it is possible to improve efficiency and productivity.

\subsection{Value drivers: Environmental dimension}

From PMs perspective, the environmental dimension is mainly related to productivity and economic factors, this is due to the fact that the business pursues to maintain productivity levels, reducing or optimizing the use of resources, which in turn translate into better results. Although with the increase in water use efficiency, the generation of renewable energies and the circular economy are intensely promoted by the Aqualogy, managers have perceived difficulties in translating these efforts into a sound differentiation of their value proposition; this is due to PMs don't know highlight the potential capability in environmental values, even they are inherent. On the other hand, the spectrum of the understanding framework has been centred for a long time on economic interests of the supplier-client relationship.

In figure 4, the implication of the PS-3 with resource dependency stands out $(98 \%)$, concentrating the proposal in prompt the circular economy (82\%). The PSs- $(2,6,9$ and 10) have proposals focused on managing and recovering waste (scores from 20 to 50\%). For their part, the PSs- (4 and 9) are aimed at reducing the emission of pollutant load (law commitments). Meanwhile, with very low levels of potential capabilities for creating environmental values are PSs- (1, 2, 7, and 8). 


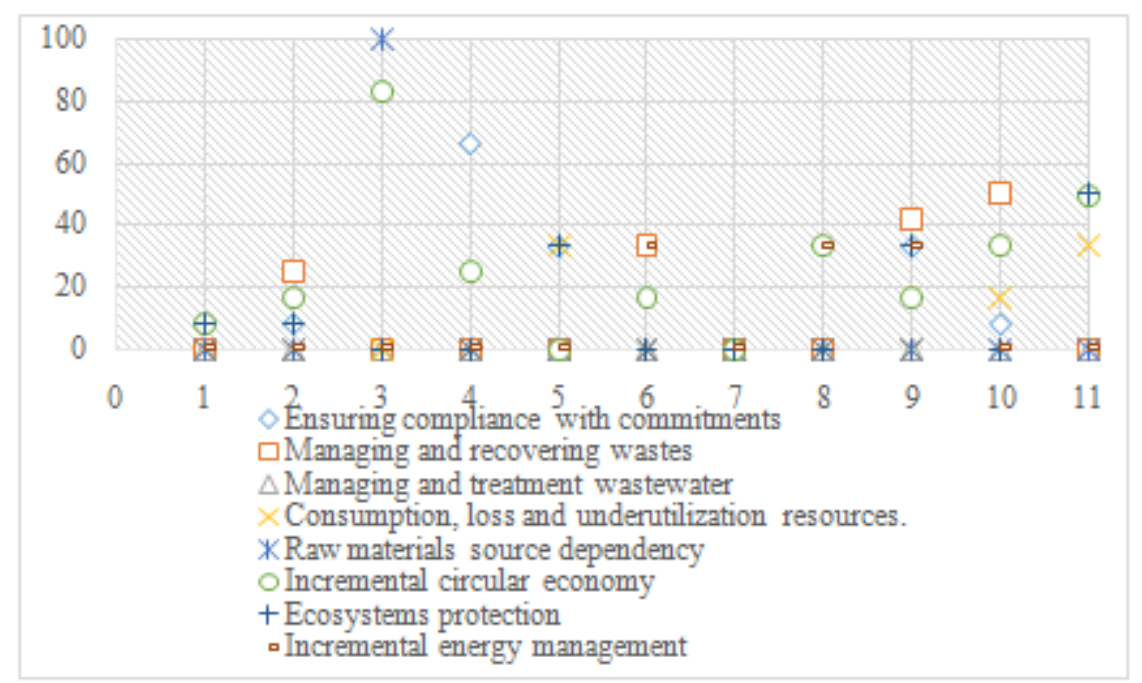

Figure 4. Capability to create environmental values

Projecting to reach a high level of positioning in sustainability is complicated since there is the temptation to exaggerate some attributes at the expense of subtracting transcendence from others. In this sense, the differential factor lies in offering a strong value proposition with respect to the central benefits, contributions or values provided by the PS, always highlighting the chain of positive consequences that the value creation process entails. It is important to emphasize that the purpose of this framework of understanding is to reduce value dissonances and emphasize the inherent benefits of the supplier-client relationship in order to generate effective synergies around the continuous improvement of products and services performance.

\section{Conclusion}

Although the term 'sustainability' is widely known, it is difficult for companies, business-makers, and customers to process it clearly and completely, mainly because it is a concept too broad, ambiguous and complex (Berns et al., 2009; Dyllick \& Muff, 2016). The meaning of sustainability and value concepts in business modelling is the major reasons that decision-makers have not fully embedded sustainability in the mainstream business scope (Dyllick \& Muff, 2016; Bocken et al., 2014). This is even more remarkable in B2B business environments, where it is not easy to identify the sustainability's contributions or impacts on business, in fact, measure them it is even more difficult; this happen mainly because clients and companies consider different valuation criteria and give unequal importance to all the SRI which are part of global challenges (value dissonances) (Pinnington et al., 2016).

In the business field, the influence of executive decisions are important to fully embed sustainability in the mainstream business, and through that, empowering the enhancement of service capabilities, create competitive advantage and works toward sustainability challenges. Literature review evidenced that decision-makers and managers overall lack a common framework of relevant sustainability drivers and issues for facing the challenge of embedding them into the portfolio, business models, marketing strategies, technologies, and manufacturing processes. This lack is the reason why the study goal focused on determining a set of common set of sustainability-related issues (SRI) and drivers (SVD) relevant for a particular business sector, in order to be used as an understanding framework for inter-organizational communications and so, to reduce value perception dissonances on supplier-client business relationships. For the achievement study goal, it was proposed to focus on the business scope of a company in the water industry sector.

The methodology followed was based on a documentary research method and experimental implementation (interviews, workshop, and discussion) with a focus group composed of decision-makers in the Aqualogy's business scope, a servitized company in the water industry sector. As the outcome, there was identified a set of 24 common SRI, which themselves becomes in the understanding framework (24 SVD) for supporting managers and decision-makers in their business relationships. 
From these outcomes, a case study was proposed, in order to validate its usefulness, seeking to identify how many of SVD are embedded in the Aqualogy's portfolio. For this, it was taken as a base the framework of 24 SVD to know the product managers' value perception (PM) in regards to solutions' capacity (a set of productsservices) to create sustainability values in current business relationships. The case study seeks to help managers in shed light on the importance of aligning SRI on business model development to better understood and clarified their contributions, and so to address the challenge of embedding them in business relationships.

For this, a number of 11 solutions were chosen as analysis units (the sample of products-services represents $12 \%$ of the total portfolio offering). As a result, case study showed that from a global assessment PMs don't easily perceive the full potential value which can be derived from the potential capabilities of every solution. Indeed, most of them allocate a greater emphasis on economic and social value drivers than environmental value drivers. Results to confirm that not only is necessary to assess value perception outside the company, it is also necessary to analyse how managers calculates the total contribution of every single business unit (as value proposal), in order to re-design the business models and highlight the contributions derived from the business relationship. The framework allows managers to estimate the potential capabilities of the solutions, and thereby considering its value offering in an integral way.

Finally, the study shed lights over importance to align sustainability values for inter-organizational communications by means of identifying SRI and SVD in the business relationship. The framework of understanding that emerged from this document should not be used as a standard for other companies, due to the particular interests of Aqualogy and its clients.

\subsection{Theoretical contribution}

The study makes some contributions to sustainability management research and business literature. The study provides insights to go step to a better understanding of the meaning of sustainable value and its relevance to business. Also, the results afford empirical evidence of how sustainability management can support the business model design. Prior studies suggest that taking as a starting point the multiples-stakeholders' interest and requirements, as well as the global sustainability challenges along the life cycle of products and services, may help companies in their business modelling process for embedding sustainability into the company's core business and its business network. But, these studies have not provided detailed insight about how managers understand and perceive the sustainability concept in the mainstream business. This study responds to calls for more detailed insights about SRI as starting point for managers (Berns et al., 2009; Dyllick \& Muff, 2016). In addition, the study provides insights on value frameworks for business development, as increased those frames may partially explain to managers how to focus business model design on achieving the sustainability performance client expect through product-service provision.

\subsection{Practical contribution}

Innovate in sustainability values seems a key factor in business modelling, because allowing companies to create the value clients expected, and driving toward an effective assessment of the business contributions to global challenges. This study sheds light on the importance of aligning business expectations around sustainability, and create a value framework that can be useful for fully embedding sustainability into the portfolio, business models, marketing strategies, technologies, and manufacturing processes. This framework can also be useful for analysing value dissonances on supplier-client relationships, identifying value gaps into business models.

\subsection{Limitations and future research}

The limitations of this study open-up the opportunity to seek advance and achieve concrete insights into the business for sustainability field by future research. Despite the study considered both a literature review and a focus group, the final set of SRI presented aren't an exhaustive and are delimited by a particular scenario. This means that it cannot be used or considered as a standard application model for other companies. Therefore, any future research would do well study a much broader literature review as well as consider a further expert group, including other stakeholders in the related sector, in order to reduce the fails of a very biased set of SRI. This 
study is just one step for in a business modelling process based on the triple bottom line. In this sense, further work is recommended to refine and enhance a complete framework which helps to support managers in innovating or improving the business models.

\section{Acknowledgments}

We would like to thank the Aqualogy's product managers and clients who participated with their valuable contribution for performing this study. Likewise, we gratefully acknowledge the support of the Agència de Gestió $d^{\prime}$ Ajuts Universitaris i de Recerca of the Generalitat de Catalunya and their contribution to Industrial Doctorate Plan.

\section{Declaration of Conflicting Interests}

The authors declared no potential conflicts of interest with respect to the research, authorship, and/or publication of this article.

\section{Funding}

The authors received financial support for the research from the Generalitat de Catalunya through the Agència de Gestió d'Ajuts Universitaris i de Recerca of the Generalitat de Catalunya and its program 'Industrial Doctorate Plan'.

\section{References}

Ambrose, E., Marshall, D., \& Lynch, D. (2010). Buyer supplier perspectives on supply chain relationships. Int. J. Oper. Prod. Manag., 30(12), 1269-1290. https://doi.org/10.1108/01443571011094262

Ballantyne, D., Frow, P., Varey, R.J., \& Payne, A. (2011). Value propositions as communication practice: Taking a wider view. Industrial Marketing Management, 40(2), 202-210. https://doi.org/10.1016/j.indmarman.2010.06.032

Berns, M., Townend, A., Khayat, Z., Balagopal, B., Reeves, M., Hopkins, M. et al. (2009). The Business of Sustainability: Imperatives, Advantages, and Actions. The Boston Consulting Group (BCG).

Biju, P.L., Shalij, P.R., \& Prabhushankar, G.V. (2015). Evaluation of customer requirements and sustainability requirements through the application of fuzzy analytic hierarchy process. Journal of Cleaner Production, 108, 808-817. https://doi.org/10.1016/j.jclepro.2015.08.051

Bocken, N.M.P., Short, S.W., Rana, P., \& Evans, S. (2014). A literature and practice review to develop sustainable business model archetypes. Journal of cleaner production, 65, 42-56. https://doi.org/10.1016/j.jclepro.2013.11.039

Bocken, N., Short, S., Rana, P., \& Evans, S. (2013). A value mapping tool for sustainable business modelling. Corporate Governance, 13(5), 482-497. https://doi.org/10.1108/CG-06-2013-0078

Buxel, H., Esenduran, G., \& Griffin, S. (2015). Strategic sustainability: Creating business value with life cycle analysis. Business Horizons, 58, 109-122. https://doi.org/10.1016/j.bushor.2014.09.004

Chandler, J.D., \& Lusch, R.F. (2015). Service systems a broadened framework and research agenda on value propositions, engagement, and service experience. J. Serv. Res., 18(1), 6-22. https://doi.org/10.1177/1094670514537709

Chou, C.-J., Chen, C.-W., \& Conley, C. (2015). Creating sustainable value through service offerings. Research Technology Management, 58(2), 48-55.

de Chernatory, L., Harris, F., \& Dall'Olmo Riley, F. (2000). Added value: Its nature, roles and sustainability. Eur. Journal Marketing, 34(1/2), 39-56. https://doi.org/10.1108/03090560010306197

Dyllick, T., \& Muff, K. (2016). Clarifying the meaning of sustainable business: Introducing a typology from business-as-usual to true business sustainability. Organization \& Environment, 29(2), 156-174. https://doi.org/10.1177/1086026615575176 
Evans, S., Fernando, L., \& Yang, M. (2017). Sustainable Value Creation-From Concept Towards Implementation. In R. Stark, G. Seliger \& J. Bonvoisin (eds), Sustainable Manufacturing. Part of the series Sustainable Production, Life Cycle Engineering and Management (pp. 203-220). Springer: Cham. https://doi.org/10.1007/978-3-319-48514-0_13

Faulkner, W., \& Badurdeen, F. (2014). Sustainable Value Stream Mapping (Sus-VSM): Methodology to visualize and assess manufacturing sustainability performance. Journal of Cleaner Production, 85, 8-18.

https://doi.org/10.1016/j.jclepro.2014.05.042

Figge, F., \& Hahn, T. (2004). Sustainable value added-measuring corporate contributions to sustainability beyond eco-efficiency. Ecological economics, 48(2), 173-187. https://doi.org/10.1016/j.ecolecon.2003.08.005

Ford, D., \& Mouzas, S. (2013). Service and value in the interactive business landscape. Ind. Mark. Manag., 42(1) (2013), 9-17. https://doi.org/10.1016/j.indmarman.2012.11.003

Graham, R., \& Bertels, S. (2006). Achieving Sustainable Value: Sustainability Portfolio Assessment. Greener Management International, 54, 57-67. https://doi.org/10.9774/GLEAF.3062.2006.su.00010

GRI (2013). Sustainability topics for sectors: What do stakeholders want to know (pp. 1-156). Amsterdam: Global Reporting Initiative.

Haugh, H.M., \& Talwar, A. (2010). How do corporations embed sustainability across the organization?. Academy of Management learning and education, 9(3), 384-396. https://doi.org/10.5465/AMLE.2010.53791822

Hoekstra, A.Y. (2015). The sustainability of a single activity, production process or product. Ecological Indicators, 57, 82-84. https://doi.org/10.1016/j.ecolind.2015.04.022

Hohenschwert, L., \& Geiger, S. (2015). Interpersonal influence strategies in complex BtoB sales and the sociocognitive construction of relationship value. Industrial Marketing Management, 49, 139-150. https://doi.org/10.1016/j.indmarman.2015.05.027

Hohenthal, J., Johanson, J., \& Johanson, M. (2014). Network knowledge and business-relationship value in the foreign market. International Business Review, 23(1), 4-19. https://doi.org/10.1016/j.ibusrev.2013.08.002

Huang, L., Milne, D., Frank, E., \& Witten, I.H. (2012). Learning a concept-based document similarity measure. Journal of the American Society for Information Science and Technology, 63(8), 1593-1608.

https://doi.org/10.1002/asi.22689

Juwana, I., Perera, B.J.C., \& Muttil, N. (2010). A water sustainability index for West Java-Part 2: Refining the conceptual framework using Delphi technique. Water Sci. and Tech., 62(7), 1641-1652.

https://doi.org/10.2166/wst.2010.453

Kuosmanen, T., \& Kuosmanen, N. (2009). Role of benchmark technology in sustainable value analysis: An application to Finnish dairy farms. Agricultural and Food Science, 18 (3-4), 302-316.

Lacoste, S., \& Johnsen, R.E. (2015). Supplier-customer relationships: a case study of power dynamics. J. Purch. Supply Manag., 21(4), 229-240. https://doi.org/10.1016/j.pursup.2014.12.006

LaPlaca, P.J. (2013). Research priorities for BtoB marketing researchers. Revista Española de Investigación en Marketing ESIC, 17(2), 135-150. https://doi.org/10.1016/S1138-1442(14)60027-9

Lozano, R. (2012). Towards better embedding sustainability into companies' systems: An analysis of voluntary corporate initiatives. Journal of Cleaner Production, 25, 14-26. https://doi.org/10.1016/j.jclepro.2011.11.060

Lusch, R.F., Vargo, S.L., \& Tanniru, M. (2009). Service, value networks and learning. Journal of the Academy of Marketing Science, 38(1), 19-31. https://doi.org/10.1007/s11747-008-0131-z

Marchi, V.D.S. (2013). Environmental strategies, upgrading and competitive advantage in global value chains. Business strategy and the environment, 22(1), 62-72. https://doi.org/10.1002/bse.1738

Meehan, J., \& Wright, G.H. (2013). Power priorities in buyer-seller relationships: A comparative analysis. Ind. Mark. Manag., 42(8), 1245-1254. https://doi.org/10.1016/j.indmarman.2013.07.023 
Mogalakwe, M. (2009). The documentary research method-using documentary sources in social research. Eastern Africa Social Science Research Review, 25(1), 43-58. https://doi.org/10.1353/eas.0.0006

Nidumolu, R., Prahalad, C.K., \& Rangaswami, M.R. (2009). Why sustainability is now the key driver of innovation. Harvard Business Review, 57-64.

O'Cass, A., \& Ngo, L.V. (2012). Creating superior customer value for BtoB firms through supplier firm capabilities. Industrial Marketing Management, 41(1), 125-135. https:/ / doi.org/10.1016/j.indmarman.2011.11.018

Peat, R.O.S.S. (2003). Values drive value. University of Auckland Business Review, 5(2), 1-11.

Pinnington, B.D., Meehan, J., \& Scanlon, T. (2016). A grounded theory of value dissonance in strategic relationships. J. Purchasing and Supply Management, 22(4), 278-288. https://doi.org/10.1016/j.pursup.2016.04.005

Prior, D.D. (2012). The effects of buyer-supplier relationships on buyer competitiveness. J. Bus. Ind. Mark., 27(2), 100-114. https://doi.org/10.1108/08858621211196976

Renard Y.J.S. (2015). A review of corporate sustainability reporting tools (SRTs). Journal of Environmental Management, 164, 180-195. https://doi.org/10.1016/j.jenvman.2015.09.010

Roeder, I., Scheibleger, M., \& Stark, R. (2015). How to make people make a change: Using social labelling for raising awareness on sustainable manufacturing. Procedia CIRP, 40, 359-364. https://doi.org/10.1016/j.procir.2016.01.065

Schaltegger, S., Lüdeke-Freund, F., \& Hansen, E.G. (2012). Business cases for sustainability: The role of business model innovation for corporate sustainability. International Journal of Innovation and Sustainable Development, 6(2), 95-119. Retrieved from SSRN: https://ssrn.com/abstract=2010510 https://doi.org/10.1504/IJISD.2012.046944

Slabbert, Y., \& Barker, R. (2014). Towards a new model to describe the organisation-stakeholder relationshipbuilding process: A strategic corporate communication perspective. J. Comm. Theory and Research, 40(1), 69-97. https://doi.org/10.1080/02500167.2014.875481

Tukker, A. (2015). Product services for a resource-efficient and circular economy - a review. Journal of Cleaner Production, 97(15), 76-91. https://doi.org/10.1016/j.jclepro.2013.11.049

Van Passel, S., Van Huylenbroeck, G., Lauwers, L., \& Mathijs, E. (2009). Sustainable value assessment of farms using frontier efficiency benchmarks. Journal of Environmental Management, 90(10), 3057-3069. https://doi.org/10.1016/j.jenvman.2009.04.009

Vandaele, N.J., \& Decouttere, C.J. (2013). Sustainable R\&D portfolio assessment. Decision Support Systems, 54(4), 1521-1532. https://doi.org/10.1016/j.dss.2012.05.054

Wilson D.T., \& Jantria S. (1994). Understanding the value of a relationship. Asia-Aust Marketing Journal, 2(1), 55-66. https://doi.org/10.1016/S1320-1646(94)70278-1

Xing, K., Wang, H.F., \& Qian, W. (2013). A sustainability-oriented multi-dimensional value assessment model for product-service development. Int J Prod Res, 51(19), 5908-5933. https://doi.org/10.1080/00207543.2013.810349

Yang, M., Vladimirova, D., Rana, P., \& Evans, S. (2014). Sustainable value analysis tool for value creation. Asian Journal of Management Science and Applications, 1(4), 312-332. https://doi.org/10.1504/AJMSA.2014.070649

Zijp, M.C., Heijungs, R., van der Voet, E., van de Meent, D., Huijbregts, M. A., Hollander, A., et al. (2015). An identification key for selecting methods for sustainability assessments. Sustainability, 7(3), 2490-2512. https://doi.org/10.3390/su7032490 


\section{Appendix A. Eight archetypes for explain business model innovation for sustainability}

The archetypes defined by Bocken et al., (2014) provide mechanisms to assist the innovation process for embedding sustainability in business models. The eight archetypes identified are:

1. Maximize material and energy efficiency

2. Create value from 'waste'

3. Substitute with renewables and natural processes

4. Deliver functionality, rather than ownership

5. Adopt a stewardship role

6. Encourage sufficiency

7. Re-purpose the business for society/environment

8. Develop scale-up solutions

Above there are a series of ideal patterns (archetypes) to integrate sustainability into the business relationship around the industrial water sector. Please respond according to your expectations, this is not an assessment, then there are no good or bad answers; we just want to know your opinion and perception of it.

Instructions: Mark with an "X" those sustainability-related issues that best represents the eight archetypes according to your perception.

\begin{tabular}{|c|c|c|c|c|c|c|c|c|c|}
\hline \multicolumn{2}{|r|}{ Sustainability-Related Issues } & \multicolumn{8}{|c|}{ Archetypes for sustainability } \\
\hline & Economic pillar & 1 & 2 & 3 & 4 & 5 & 6 & 7 & 8 \\
\hline 1 & $\begin{array}{l}\text { Providing and boost alternatives like renting, financing, cost sharing, } \\
\text { etc. }\end{array}$ & & & & & & & & \\
\hline 2 & $\begin{array}{l}\text { Encouraging customers to moves to functionality benefits, rather than } \\
\text { ownership focus. }\end{array}$ & & & & & & & & \\
\hline 3 & $\begin{array}{l}\text { Ensuring competence and effectiveness organizational through } \\
\text { practices and strategies. }\end{array}$ & & & & & & & & \\
\hline 4 & Making real the fair trade from a monetary balance-point. & & & & & & & & \\
\hline 5 & $\begin{array}{l}\text { Managing to ensure optimizing the expenses and cost regarding } \\
\text { operations and consumptions. }\end{array}$ & & & & & & & & \\
\hline 6 & Ensuring the purchasing of "green" supplies, products and materials & & & & & & & & \\
\hline 7 & Promoting the adjustment of economic policies for sustainability. & & & & & & & & \\
\hline 8 & Optimizing production performance by means of products-services & & & & & & & & \\
\hline 9 & $\begin{array}{l}\text { Changing trade agreements for driving the enhancement of } \\
\text { purchasing patterns. }\end{array}$ & & & & & & & & \\
\hline 10 & $\begin{array}{l}\text { Utilizing suppliers who share with company the sustainability } \\
\text { commitment. }\end{array}$ & & & & & & & & \\
\hline 11 & $\begin{array}{l}\text { Ensuring an incremental economic performance at the long or } \\
\text { medium term. }\end{array}$ & & & & & & & & \\
\hline 12 & Applying discounts to promote sustainable purchasing decisions. & & & & & & & & \\
\hline 13 & Managing and boost innovation, creativity and technological insights. & & & & & & & & \\
\hline 14 & $\begin{array}{l}\text { Managing adaptability and flexibility to create, design or restructuring } \\
\text { products-services and activities }\end{array}$ & & & & & & & & \\
\hline 15 & $\begin{array}{l}\text { Promoting and managing business relationships for knowledge } \\
\text { development. }\end{array}$ & & & & & & & & \\
\hline 16 & Supporting supplier firms to develop innovative solutions. & & & & & & & & \\
\hline 17 & Driving industrial processes to the resource efficiency management. & & & & & & & & \\
\hline 18 & $\begin{array}{l}\text { Supporting supplier firms through commitments to ensure the fair } \\
\text { trade. }\end{array}$ & & & & & & & & \\
\hline 19 & Reverting to customers a percentage of the economic performance. & & & & & & & & \\
\hline 20 & Implementing resource-saving measures within industrial process & & & & & & & & \\
\hline
\end{tabular}




\section{Appendix B. Business sustainable typology}

According to Dillick and Muff, (2016) the truly sustainable organizations ask themselves more challenging questions, understanding how it can create a significant positive impact in critical and relevant areas for society and the planet. Therefore they formulated six questions to distinguish if a business is really sustainable. Five of six original questions were modified to fit them to the study goal:

1. Which of the sustainability related issues could be resolved by dedicating our wealth of resources, competencies, talents, and experiences?

2. What are the sustainability benefits and contributions of products and services in the mainstream business?

3. Which of the sustainability related issues can help to transform solutions?

4. How the sustainability related issues can help to develop decision making structures to respond more effectively to business's concerns?

5. What sustainability related issue can we need individually to engage in sector-wide or cross-sectorial strategies?

6. Where do we need to engage in activities to change the rules of the game to bring together the divergent demands of the current economic system and the demands of SD?

Intangible Capital, 2018 (www.intangiblecapital.org)

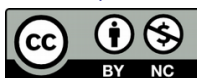

Article's contents are provided on an Attribution-Non Commercial 4.0 Creative commons International License. Readers are allowed to copy, distribute and communicate article's contents, provided the author's and Intangible Capital's names are included. It must not be used for commercial purposes. To see the complete license contents, please visit https://creativecommons.org/licenses/by-nc/4.0/. 